\title{
The Intersection of Civic Engagement and Civic Attitudes Among Latino Youth Through a Factor Analysis
}

\author{
Nicole Webster \\ The Pennsylvania State University \\ Erica Sausner \\ The Pennsylvania State University \\ Bader Alotaibi \\ King Saud University \\ Ashley Patterson \\ The Pennsylvania State University
}

\begin{abstract}
The extent to which civic and citizenship education captures the ways Latino youth perceive their roles as social change agents is largely absent from academic literature. This article examines how youth perceptions of and interactions with civic education define the civic lens they apply to their societies. The article examines a new way of interpreting the International Civic and Citizenship Study data and how it investigates new ways to view the civic lens of youth within three Latin American countries. Results of the exploratory factor analysis indicate a three-factor structure of civic lenses and show that youth who have been exposed to particular postconflict ideologies have developed a basic national understanding of civics. Findings provide insight into the utility of a tool for assessing youths' notions of social agents of change based upon pertinent civic perspectives. Such assessment may identify factors to be addressed by organizations seeking to deepen understanding and increase meaningfulness of civic action for youth.
\end{abstract}

Keywords: Latin America, youth, civic engagement, social change

\section{Introduction}

Exploration of the narratives of several Latin American countries uncovers turbulent economic and social histories that have shaped how individuals interact with their national governments and amongst themselves. More importantly, these interactions and beliefs are often informally passed on from generation to generation in the form of oral history and political movements and shape an individual's civic beliefs, mores, and actions. Some scholars contend that histories have shaped forms of activism, civic engagement, and citizenship—and, more importantly, one's outlook on life. Such interactions have developed along age, gender, race, and political synergies between and among groups, expanding propensities to exhibit civic autonomy and action.

Due to the systemic silencing of marginalized citizens in societies, there is always the need to create alternative spaces for inclusion and equity in these contexts. One group that has played a pivotal role in civic spaces as seen in recent global movements is youth. Events such as the Palestinian youth revolt (Burton, 2017), Burkina's Revolution 2.0 (Webster, 2015), or civic uprisings among European youth (Harvey, Roberts, \& Dillabough, 2016) have highlighted their involvement in spaces 
to improve society's' quality of life. Despite these worldwide movements, young people's civic involvement across the global south has received less than equal attention in studies on social engagement and social change. Apart from their participation in political spheres, youth are available as conscious voices of society and are offering clear and robust responses to social ills and injustices (Simeon, 2015). It behooves researchers and practitioners interested in understanding social change-especially in postconflict societies - to consider the specific ways in which youth participate. In this article, we seek to understand how, through civic education, young people are shaping and framing their civic activities in their immediate surroundings. We use data from the International Civic and Citizenship Study (ICCS) study to identify three areas within which youth can demonstrate their civic engagement through the articulation of their perceptions and their democratic actions. By considering these perceptions and activities as contributing factors of one bigger picture, we arrive at a more realistic understanding of the multifaceted ways youth participate in society, a concept we define as a holistic civic lens (HCL).

\section{Contextualizing a Holistic Civic Lens}

Citizens have a lens by which they look at society and how they choose to position themselves as change agents that provides a deeper perspective and engagement of a HCL. More fully, an HCL serves as a basis for individuals to understand and engage with their civic agency. The construction of a civic lens is not designed to replace civics or citizenship education or studies of the same. Instead, the HCL is a way to put different frames around understanding society and civic (dis)engagement from a pertinent perspective-in our case, the Latin American perspective.

\section{Youth as Agents of Change}

The concept of youth as citizens of change has been explored in many streams of literature because of its indicator of youth's potential contribution to social change. Much of the literature on young people and social change begins from a baseline assumption of the apathy of youth when it comes to involvement in civic activities. However, when youth see themselves as actors in civic spaces as a result of circumstances including their voices being heard and given specific responsibilities, youth show the potential to become actively engaged in civic affairs in various roles such as community organizers, planners, and facilitators (Crick, 2017; Hipolito-Delgado \& Zion, 2017; Ho, Clark, \& Dougherty, 2015).

In the Latin American context, societal-level definitions of social change and civic engagement are often in flux due to a number of nations currently engaged in or having recently emerged from conflict. Related to this status, researchers often consider aspects of youth engagement regarding social movements. Oliart and Feixa (2012) emphasized that in the 1950s, with a wave of political transitions in Latin America, philosophers focused on the role of youth in establishing a nation's cultural and political temper. Further, they argued that as time went on, philosophers conceived of youth as the source of social problems and eventually considered them to be citizens rolled into the polity and in need of training. It is through this engagement with society at large that youth are establishing their definitions of and involvement with citizenship-related activity, acts that fundamentally cement their place as social change agents in society. In one example of a study of citizenship education in Colombian schools, Edwards (2012) investigated how school-level factors interrupted apathetic stances and impacted the development of social movement-oriented youth. Findings from this study emphasized that school-level factors such as curriculum, teachers, and classroom environment contributed to the development of social movement-oriented citizenship attitudes and behaviors. 


\section{Positioning an Approach to Social Action and Change}

Today, we are faced with a new global and national transformation that obliges us to recognize that knowledge of civics and social change is based on an understanding of societal norms, government, and laws that are necessary. However, they are often deemed as insufficient to prepare citizens of the future, especially in the context of making youth adapt and ready to become agents of social change. The world has changed, and is increasingly complex, subject to inter- and intrastate relationships and migration patterns shifting communities and populations. The emergence of women in social and political settings, indigenous peoples fighting for rights, and the disenfranchised or persecuted and exiled by wars are just a few of the many challenges faced by citizens in the Latin American region. Populations have often been excluded from social services and more importantly from civic, political agendas due to age, sexuality, ethnicity, and social condition. This systemic exclusion reinforces the necessity to have conversations that move beyond awareness of issues and toward creating democratic and participative spaces that can lead to solutions that have long-term impact and meaning.

The ongoing processes of transition and democratic consolidation have opened up questions young people may be asking about social change and civic engagement including what it means to be an engaged citizen, how one becomes civically involved, and whether it is even necessary to become involved to institute meaningful change within a society. Similar ponderings inspired us as we determined an appropriate approach for thinking about youth and their propensity to contribute to social change given the information collected via the ICCS.

\section{Method}

\section{General ICCS Assessment Framework}

Data for this project came from the ICCS dataset, which investigates how young people in a number of countries are prepared to undertake their roles as citizens in the second decade of the 21st century. ICCS is mainly concerned with student achievement as measured by a test of knowledge, conceptual understanding, and competencies in civic and citizenship education. It also questions about students' attitudes and perceptions relating to civics and citizenship. Additionally, the survey gathers information about the contexts in which students learn about these issues.

Cognitive test items provided the general assessment framework for the ICCS to measure a single trait labeled civic knowledge. Civic knowledge was expressed through the test items that required students to apply the cognitive processes to the civics and citizenship content as described in the assessment framework (Schulz, Ainley, Fraillon, Kerr, \& Losito, 2010).

\section{Latin American Instrument}

Due to national and political nuances identified by the ICCS regional experts who were scholars from each of the six Latin American participating countries (Chile, Colombia, Dominican Republic, Guatemala, Mexico, and Paraguay), a regional instrument was designed in line with a regional framework and linked to the international context. Specificities included the current trends in regional terms and definitions which helped delineate the knowledge, attitudes and values, and competencies to be investigated in addition to aspects already measured with the international instruments (Schulz, Ainley, \& Fraillon, 2011).

The Latin American ICCS civic knowledge test consisted of 16 multiple-choice items and 78 Likert items including perceptions and region-specific civic knowledge variables that focused on specific 
aspects of knowledge relevant to the Latin American region. Although the test items were specially developed for students in Latin American countries and thus addressed elements not relevant in other geographical parts of the world, the regional test items were designed to measure the same content and cognitive dimensions as those on the international test.

\section{Sample}

Six Latin American countries participated in establishing the regional competencies. For this study, we have focused on three postconflict countries: Guatemala, Colombia, and Chile. Each of these countries has experienced detrimental wars that resulted in wide-scale national instabilities in security and safety, economic growth, and political progress, as well as fragile health systems. Combined, these issues have led to long-term impacts and radical changes on the social cohesion and social structures of communities and families.

The civic lens of students in postconflict societies is crucial for understanding how these nations continue to develop and engage with democratic practices. Similarly, given that curricula in civics and citizenship education are designed for their respective context, we chose these countries to understand better what political priorities have been successfully passed down to students.

\section{Participants}

Regardless of location, all students in the ICCS sample were enrolled in the eighth grade (the mean age of students at the time of testing in 2009 was 13.5 years). The largest number of participants of our three sampled countries were from Columbia $(n=5,512)$ and Chile $(n=5,009)$. While Guatemala $(n=2785)$ had the least amount of student participants, they had the highest percentage (0.05\%) of non-native participants of all three countries. Each of the three countries had almost equal participation across gender with female participants (53\%) slightly outnumbering males sampled.

\section{Statistical Analysis}

An exploratory factor analysis (EFA) was used to discover the factor structure of the civic lens measure and to examine its internal reliability. EFA allows the identification of linear factors that explain the theoretical maximum amount of common variance in a correlational matrix (Marsh, Morin, Parker, \& Kaur, 2015), which will determine the underlying factor model that best fits the data. We hypothesized that a simple structure would occur, with most items having a large loading on one factor with small loadings on the other factor(s). After the initial solution, the loadings were rotated. Rotation is a way of maximizing high loadings and minimizing low loadings so that the simplest possible structure is achieved. An oblique rotation was then used in an attempt to achieve simple structure, allowing the factors to be correlated.

Our analysis includes data from three countries (Chile, Colombia, and Guatemala). Thus, 13,306 respondents completed the survey (6,973 girls and 6,333 boys). Brown (2014) recommended a sample size of at least 300 participants and at least five to 10 observations for variables subjected to factor analysis to provide reliable results. The determination of factors to extract must be guided by theory, a process which yields the most interpretable results. We used orthogonal rotation (varimax) as suggested by Osborne (2015) because we assumed our factors were independent.

The Kaiser-Meyer-Olkin measure of sampling adequacy and the Bartlett's test of sphericity were performed to confirm that the factor analysis was adequate with the data under consideration. Thus, a value of Kaiser-Meyer-Olkin measure of sampling adequacy, .915 and significant value of Bartlett's test of sphericity $(p<.001)$ indicated that the data were appropriate for factor analysis. We 
also checked for multicollinearity and singularity within the data as suggested by Loewen and Gonulal (2015). Using a scree plot, the factor analysis showed that three distinct factors with an Eigenvalue $>1$ were extracted. Moreover, there was no item cross loading in the rotated component matrix.

After the exploratory factor analysis was completed, we analyzed only the items that had an Eigenvalue $\geq 0.3$. The questions were assigned labels corresponding with larger concepts in social change literature. The items were then grouped based on their content. In doing so, we were able to group the items into three categories made up of Likert-scale questions reflecting the perceptions held by and actions undertaken by youth. Each of these categories contributes to the civic lenses of young people in these three related but distinct Latin American countries.

\section{Results}

Application of these methods to the ICCS survey conducted in Chile, Colombia, and Guatemala resulted in 54 of the 78 survey items producing Eigenvalues above the cut-off point of 0.3. Analysis of these grouped items (see tables) resulted in our identification of three dimensions of students' civic lenses that together make up what we title the HCL. The three dimensions are action and perception of national identity, democracy as action, and reflection and expanding on power and status quo. These concepts, and the specific test items associated with each, merit consideration in the postconflict Latin American context using the ICCS data. Identification of these three constructs helps to illustrate the otherwise esoteric concept of HCL concretely.

As result of factor analysis, we identified nine attitudinal items contributing to Factor 1, Action and Perception of National Identity (Table 1). The nine items accounted for $10.06 \%$ of the total explained variance. As the label implies, the construct consists of variables relating to students' perceptions of how they could express their national identities. This was especially important in the context of the three countries included in the analysis because of their shared political histories. We recognize that not all Latin American countries share a homogenous national identity, but it can be argued that youth generally see themselves as being able to take part in activities that express national pride. Responses to prompts such as "proud to live in country" and "great respect for country" provided insight into perceptions youth held about their duty to be part of a collective unit (e.g., a citizen of the country).

Table 1. Action and Perception of National Identity

\begin{tabular}{lc}
\hline Item & Factor Loading \\
\hline Religion should influence people's behavior toward others. & 0.33 \\
As an adult, I will be able to take part in politics. & 0.33 \\
Religion helps me to decide what is right and what is wrong. & 0.36 \\
[Country of test] shows a lot of respect for the environment. & 0.48 \\
Generally speaking, [country of test] is a better country to live in & 0.52 \\
than most other countries. & \\
The flag of [country of test] is important to me. & 0.61 \\
In [country of test], we should be proud of what we have achieved. & 0.61 \\
I have great respect for [country of test]. & 0.64 \\
I am proud to live in [country of test]. & 0.70 \\
\hline
\end{tabular}

Through the questions that compose this portion of the HCL, the ICCS survey investigates the sense of connection youth feel with their home nation, their self-confidence, and their interpersonal motivators. The conceptions of civic perspectives presented in these questions lean toward some of 
the most basic considerations found in the academic literature on social change, civics, and citizenship. Comparative understandings of the survey respondents' nation of residence, as well as general beliefs and support for normative symbols of national pride (e.g., the flag), touch on the understanding of the active context of citizenship. Moreover, focus on goals and motivations helps to shape and drive the behaviors of individuals who often tend to be civically engaged. The significance of these items in the EFA is that, in these particular postconflict locations, young people have developed understandings of basic national narratives that are separate from the political strife and challenges of the recent past and are more likely to see themselves as change agents in the future.

In Factor 2, Democracy as Action (Table 2), 8.21\% of the total variance was explained and linked to perceptions regarding activism and action for democracy. Not all items necessarily used the term democracy, but instead suggested activities that give clues to understanding democratic and social actions and fundamental conceptions of democratic rights. Items in this factor that seemed to resonate most with students were those related to ethnic rights as folded into the specification of all individuals, such as "all individuals have a chance to good jobs" and "all individuals have a chance to good education." Other statements focused on policies and perceptions toward immigrants, gender rights and how openly youth felt they could speak out against or for specific issues.

As with "Action and perception of national identity," many items in this construct reflect basic aspects of social change and citizenship. Individual rights are reflected in items such as, "all people should have their social and political rights respected." The complexity of this construct, however, is enhanced by a specific focus on gender, ethnicities, and immigration status. By grouping these items in this manner, we suggest that students express their opinions on more complex issues indicating citizenship is more than a title or possession of a national identity document, but also a practice that can be engaged in by diverse groups. Suggesting the inclusion of immigrants in voting, for example, indicates a relatively advanced democratic lens in which civic participation extends to the body politic, without limitations based on history. While the perceptions measured by the ICCS are crucial and give us insight into the messaging that youth in these LAC post-conflict societies are receiving about inclusion and civic participation, additional research is needed to understand the on-theground realities of inclusion and welcome for groups such as immigrants. The same can be said for the gender-focused questions in this component of the HCL. Although young people receive messaging around gender parity and international human rights, the cultural history and forces of machismo (a kind of sexism that privileges male power in subtle and overt ways throughout LAC) are strong. We must raise questions and further research around whether or not this generation of change agents are enacting their perceptions in meaningful ways. 


\begin{tabular}{|c|c|}
\hline Item & $\begin{array}{l}\text { Factor } \\
\text { Loading }\end{array}$ \\
\hline Democracy is different for people who have different incomes. & 0.303 \\
\hline Government actions should be held accountable. & 0.303 \\
\hline People should always be free to criticize the government publicly. & 0.307 \\
\hline $\begin{array}{l}\text { We Latin Americans have a lot in common even if we come from different } \\
\text { countries. }\end{array}$ & 0.326 \\
\hline People should be able to protest if they believe a law is unfair. & 0.349 \\
\hline $\begin{array}{l}\text { Immigrants should have the opportunity to continue speaking their own } \\
\text { language. }\end{array}$ & 0.358 \\
\hline Political protests should never become violent. & 0.36 \\
\hline $\begin{array}{l}\text { Immigrants who live in a country for several years should have the opportunity } \\
\text { to vote in elections. }\end{array}$ & 0.379 \\
\hline $\begin{array}{l}\text { Organizing groups of students to express their opinions could help solve } \\
\text { problems in schools. }\end{array}$ & 0.381 \\
\hline Men and women should get equal pay when they are doing the same jobs & 0.427 \\
\hline $\begin{array}{l}\text { Members of all ethnic/racial groups should be encouraged to run in elections for } \\
\text { political office. }\end{array}$ & 0.429 \\
\hline Everyone should always have the right to express their opinions freely. & 0.431 \\
\hline $\begin{array}{l}\text { Immigrants should have the opportunity to continue their own customs and } \\
\text { lifestyle. }\end{array}$ & 0.45 \\
\hline All people should have their social and political rights respected. & 0.461 \\
\hline All citizens should have the right to elect their leaders freely. & 0.477 \\
\hline $\begin{array}{l}\text { Immigrants should have all the same rights that everyone else in the country } \\
\text { has. }\end{array}$ & 0.505 \\
\hline Men and women should have the same rights in every way. & 0.526 \\
\hline Men and women should have equal opportunities to take part in government. & 0.532 \\
\hline Schools should teach students to respect members of all ethnic/racial groups. & 0.555 \\
\hline $\begin{array}{l}\text { Members of all ethnic/racial groups should have the same rights and } \\
\text { responsibilities. }\end{array}$ & 0.583 \\
\hline $\begin{array}{l}\text { All ethnic/racial groups should have an equal chance to get a good education in } \\
\text { [country of test]. }\end{array}$ & 0.604 \\
\hline $\begin{array}{l}\text { All ethnic/racial groups should have an equal chance to get good jobs in [country } \\
\text { of test]. }\end{array}$ & 0.617 \\
\hline
\end{tabular}

Factor 3, Reflecting and Expanding on Power and the Status Quo, includes items relating to the perceptions of laws, policies, and styles of leadership and governance (see Table 3). The factor name was generated given the specificity in statements related to power and who is perceived to hold power. The 24 items in this factor explained $3.16 \%$ of the variance. Statements in this factor asked students of their perceptions regarding law officials and specific actions towards citizens, such as "enforce authority even violating rights" or "when you don't trust officers applying law." Leadership topics such as "president's opinion is most important" or "president does not agree with Congress" were also a part of this factor and were directly linked to the perceptions students held about their president as well as other public officials' governing styles. 
Table 3. Reflecting and Expanding on Power and Status Quo

\begin{tabular}{lc}
\hline & Factor \\
Item & Loading \\
\hline Religious leaders should have more power in society. & 0.309 \\
Women are better qualified to raise children. & 0.316 \\
To achieve peace, the end justifies the means. & 0.353 \\
It is not fair for the government to commit a felony against my family. & 0.367 \\
Dictatorships are justified when they bring order and safety. & 0.371 \\
It is acceptable that a civil servant helps his or her friends by giving them & 0.378 \\
$\quad$ employment in his or her office. & 0.406 \\
Dictatorships are justified when they bring economic benefits. & 0.436 \\
A law may be disobeyed when one distrusts the authority executing the law. & 0.445 \\
A law may be disobeyed when one distrusts the enacting body. & 0.452 \\
Men are better qualified than women to be political leaders. & 0.467 \\
The most important opinion of a country should be that of the president. & 0.477 \\
Women should stay out of politics. & 0.485 \\
People in government lose part of their authority when they admit their & 0.505 \\
mistakes. & \\
When there are not many jobs available, men should have more right to a job & 0.507 \\
than women. & 0.522 \\
Concentration of power in one person guarantees order. & \\
It is fair that the government does not comply with the law when it thinks it is & 0.55 \\
not necessary. & \\
It is better for government leaders to make decisions without consulting & 0.553 \\
anybody. & \\
People in government must enforce their authority even if it means violating & \\
the rights of some citizens. & 0.554 \\
If the president does not agree with Congress, he or she should dissolve it. & 0.555 \\
People whose opinions are different from those of the government must be & \\
considered its enemies. & 0.562 \\
Good candidates grant personal benefits to voters in return for their votes. & 0.563 \\
The government should close communication media that are critical. & 0.586 \\
can keep part of them. & \\
\hline
\end{tabular}

The items that loaded on this factor were similar in that they all addressed regionally specific matters allowing for insight into how young people are experiencing civic experiences in these postconflict societies. These are difficult topics about governance for young people who may be only one generation removed from political violence. It is likely that their responses reflect school curriculum and parent and family experiences of violence, power, and political (dis)engagement or (dis)empowerment. It is fitting, then, that the components of this construct reflect complex aspects of the social change literature. Questions of domination and empowerment, for example, are indicated in the items that suggest the primacy of executive power over legislation-and are likely more representative of the lack of civic power held by minorities.

Moreover, questions about support of dictatorships are poignant, especially in this region of the world. They require complex thinking about the values of democracy alongside national history; thus, while seeming to be basic understandings of democratic values, they reflect important contextual realities. These contextual realities mirror the governmental shifts towards democratic action and participation in Latin America for the past 20 years. Items relating to governmental efficiency through concentration of power, trust, and focus on qualifications for leadership all 
emphasize the way in which many of these nation-states perceive public action and participation. An understanding of how youth perceive these important factors provides insight into how they may self-mobilize as agents of social change.

\section{Conclusion}

Based on the factor analysis, we identified three aspects of the HCL which are relevant within three Latin American countries-Guatemala, Columbia, and Chile. All students in the ICCS sample were enrolled in the eighth grade with a mean of 13.5 years at the time of testing in 2009 . We emphasize that creating groups of items and considering their relationship to social change and citizenship literature can benefit analysis of the ICCS data but, more importantly, can also help to contextualize places and spaces for youth to impact social change. In creating three components of the HCL, we call readers' and researchers' attention to the complex local realities and histories of these postconflict societies.

As cultures expand and change, we suggest that the development of civic-minded youth requires understanding that civil actions and identities stretch beyond normative activities and individual perceptions. How the adolescent survey participants view their action and perception of national identity, democracy as action, and reflection on power and expansion of the status quo are meaningful indicators of the society to come in this region of the world. When young people can identify with aspects of being part of a nation-state, they are more likely to be active and to invest in change that will benefit the country as a whole. Through media, shared resources, and international engagement, we can work toward a development-oriented HCL that leads to improved liberty for marginalized people and more stable and complex democratic engagement for citizens of all ages.

\section{References}

Brown, T. A. (2014). Confirmatory factor analysis for applied research. New York, NY: Guilford.

Burton, G. (2017). Building ties across the Green Line: The Palestinian 15 march youth movement in Israel and occupied Palestinian territory in 2011. Third World Quarterly, 38, 169-184.

Crick, B. (2017). Education for democratic citizenship: issues of theory and practice. London, United Kingdom: Routledge.

Edwards, D. B. (2012). Social movement oriented citizenship in Colombia: The effects of curriculum, pedagogy and extra-curricular activities on student orientation. Education, Citizenship and Social Justice, 7, 117-128. doi:10.1177/1746197911432597

Harvey, L., Roberts, S., \& Dillabough, J. A. (2016). Youth rising? The politics of youth in the global economy. British Journal of Sociology of Education, 37, 465-480.

Hipolito-Delgado, C. P., \& Zion, S. (2017). Igniting the fire within marginalized youth: The role of critical civic inquiry in fostering ethnic identity and civic self-efficacy. Urban Education, 52, 699-717.

Ho, E., Clarke, A., \& Dougherty, I. (2015). Youth-led social change: Topics, engagement types, organizational types, strategies, and impacts. Futures, 67, 52-62

Loewen, S., \& Gonulal, T. (2015). Exploratory factor analysis and principal components analysis. In L. Plonsky (Ed.), Advancing quantitative methods in second language research (pp. 182-212). New York, NY: Routledge. 
Marsh, H. W., Morin, A. J., Parker, P. D., \& Kaur, G. (2014). Exploratory structural equation modeling: An integration of the best features of exploratory and confirmatory factor analysis. Annual Review of Clinical Psychology, 10, 85-110.

Oliart, P., \& Feixa, C. (2012). Introduction: Youth studies in Latin America: On social actors, public policies and new citizenships. Young, 20, 329-344.

Osborne, J. W. (2015). What is rotating in exploratory factor analysis. Practical Assessment, Research \& Evaluation, 20, 1-7

Schulz, W., Ainley, J., \& Fraillon, J. (2011). ICCS 2009 technical report. Amsterdam, The Netherlands: International Association for the Evaluation of Education Achievement.

Schulz, W., Ainley, J., Fraillon, J., Kerr, D., \& Losito, B. (2010). ICCS 2009 international report: Civic knowledge, attitudes, and engagement among lower-secondary school students in 38 countries. Retrieved from http://research.acer.edu.au/civics/6/

Simeon, R. (2015). Policy divergence and social citizenship. In R. Hazell (Ed.), The state of the nations 2003 (pp. 215-230). Thorverton, United Kingdom: Imprint Academic.

Webster, N. (2015). Burkina Revolt 2.0: A new type of youth action. Unpublished manuscript, The Pennsylvania State University, University Park, PA.

The Journal of Social Change, sponsored by Walden University, welcomes manuscripts focusing on interdisciplinary research in social change that improves the human condition and moves people, groups, organizations, cultures, and society toward a more positive future.

Walden University Publishing: http://www.publishing.waldenu.edu 